\title{
Factors influencing Individual Investor Behaviour: Evidence from the Kuwait Stock Exchange
}

\author{
Sadeq J. Abul ${ }^{1}$ \\ ${ }^{1}$ General Manager, Sray for Economic Consultancy, Daeyah, Kuwait, State of Kuwait \\ Correspondence: Sadeq J. Abul. Tel: 965-6996-1246. E-mail: sadeqabul@gmail.com
}

Received: January 7, 2019

Accepted: January 14, $2019 \quad$ Online Published: February 28, 2019

doi:10.5539/ass.v15n3p27

URL: https://doi.org/10.5539/ass.v15n3p27

\begin{abstract}
This study investigates the effects of psychological factors on investor behaviour regarding the Kuwait Stock Exchange (KSE). These psychological factors are, namely: excessive optimism vs pessimism, herd behaviour and risk appetite. The data for this study obtained from KSE and a survey of a random sample of 398 individual investors. By using qualitative analysis and based on the theory of behavioural finance, the study findings show that herd behaviour, optimism and psychology risk have an impact on the individual investors' decisions. However, we did not find any evidence of overconfidence behaviour's effects on investors' decisions. To our knowledge, KSE has been examined by several researchers without taking into consideration the effects of psychological factors on individual investor decisions. This study finds that psychological factors play a significant role in individual investors' decisions regarding KSE. This study might contribute positively to the development of this field of research in (KSE).
\end{abstract}

Keywords: behavioural finance, psychological factors influencing investors decisions, kuwait stock exchange

\section{Introduction}

Finance theory assumes that investors are rational and make decisions based on profit maximisation. The heart of traditional finance is the Efficient Markets Hypothesis (EMH) that assumes that all of the information is provided to all investors without cost. Therefore, the price of stocks always reflects their intrinsic value and is reasonable (Fama, 1965, 1970 and 1991). However, the reality shows that investors in the markets are not necessarily always rational in their decisions and that other factors might affect them when they are making their investment decisions (Thaler, 2015). Therefore, this phenomenon encourages researchers to investigate the factors that may provoke irrationality among investors. Irrationality causes several problems in the market and drives the price of stocks away from its fair value. This phenomenon of investor behaviour has been studied during the last few decades under the name of "behavioural finance". This field of modern finance has made remarkable progress in the last two decades.

Moreover, behavioural finance studies the impact of psychological factors on the stock markets. Evidence from recent studies on behavioural finance guides us to think in a different way to traditional finance assumptions. In fact, by applying the psychological theory of human behaviour to the financial markets and using it as a tool for understanding investor decisions, we will be in a better position to understand the behaviour of irrational investors. L. Kengatharan and N. Kengatharan (2014) argue that psychological factors play a significant role in behavioural finance theory. They pointed out that behavioural finance studies psychological behaviour such as emotion and panic, which may influence the behaviour of individual investors. Therefore, psychology and anthropology can be used to explain irrational investor behaviour. According to behavioural finance, individual investors do not always behave in their own best interests. Mitroi (2016) argues that anomalies in prices can be studied through behavioural finance.

However, the Kuwait Stock Exchange (KSE), established in 1977, is a relatively old market among the Arab Gulf stock exchanges. It has undergone a series of transitional stages and faced four main crashes (in 1978, 1982, 1990 and 2008). The main cause of the first two crashes was investor behaviour (Al-Tuhaih, 1983), while the two more recent crises were due to the Iraqi invasion and world financial crises. For the majority of the time, traders' decisions in KSE depend too much on personal information and relationships, as well as rumours, overall performance and market trends, rather than upon reality. Abul (2003) finds non-linearity in the KSE Index returns and argues that investors in KSE are risk lovers. To our knowledge, KSE has been examined by 
several researchers without taking into consideration the effect of psychological factors on individual investor decisions. Psychological factors may play a significant role in the behaviour of individual investors in KSE. Thus, this study is based on the theory of behavioural finance, which was developed by Tversky and Kahneman (1974), Daniel, Hirshleifer \& Teoh (2002) and Thaler (2015). This study examines the impact of psychological factors on individual investors' decisions with regard to KSE.

\section{Literature Review}

Recent studies, such as Bakar and Yi, (2016), show that investors in the markets are not necessarily rational in their decisions and that other factors might affect them when they make their investment decisions. Behavioural finance studies the impact of psychological factors on the stock markets. Psychologists in this field include Edwards $(1954,1961)$, who is a pioneer in the subject of behavioural decision theory, Daniel and Hirsheileifer (2015), and Tversky and Kahneman (1974). The most important papers were written by Tversky and Kahneman (1974) whose contribution to the field of the factors explaining the human behaviour of decision making has had a significant impact on behavioural economics. Tversky and Kahneman (1979) compared several models of decision-making under risk and uncertainty with economic models of rational behaviour. According to behavioural finance, individual investors do not always behave in their own best interests. Behavioural finance provides a framework for understanding when and how people make errors. Thaler (1990) believes that behavioural finance confirms that certain economic factors may not be treated with rationality. Thus, behavioural finance combines principles from the fields of individual and social theory to understand and highlight stock market performance. Birau (2011a, 2011b, 2012) pointed out that human feelings and emotions have a serious impact on investors' decisions, and that inefficient markets can be explained by behaviour economics. Mitroi and Oproiu (2014) pointed out that behaviour bias affects the relationship between risk and returns and so concluded that high risk is not correlated with high returns, which conflicts with finance theory. Bakar and Yi (2016) argue that behavioural finance studies have proved that individual investors do not behave rationally, but their decisions are affected by their psychological feelings. Numerous studies from ASEAN and Western countries have, in fact, established that psychological factors do have a relationship with an impact on the decision-making of investors with regard to the markets; for example, Akhtar and Batool (2012) regarding the Karachi, Lahore, and Islamabad Stock Exchanges; Phan and Zhou (2014) regarding the Vietnamese Stock Market; Riaz and Hunjra (2015) and Farooq, Afzal, Sohil \& Sajid (2015) regarding the Pakistani Stock Market; Dhaoui (2015) regarding the Japanese, U.S., French, U.K., and Swiss Stock Markets; Shabgou and Mousavis (2016) regarding the stock exchange in Tabriz, Iran; and, finally, Gupta and Ahmed (2016) regarding the Indian Stock Market. Decision errors can be due to human mind behaviour. Moreover, Camerer and Loewenstein $(2004$, p.3) stated that "behavioural economics increases the explanatory power of economics by providing it with more realistic psychological foundations". There are four main psychological factors that affect individual investors' decisions. These are as follows:

2.1

Overconfidence, where investors believe that they possess more knowledge than other investors (Shiller, 2015). The overconfidence phenomenon has been studied by numerous researchers, including Barber and Odean (2001), Hirshleifer and Luo (2001), Wang (2001), Scheinkman and Xiong (2003), Ton and Dao (2014), and Daniel and Hirshleifer (2015). Ton and Dao (2014) argue that overconfident investors believe that they can gain more from the market by using their emotions, even though this is impossible. The same authors found in their study that $70 \%$ of the Vietnamese Stock Exchange investors are overconfident about managing their portfolio. However, selfish investors, who consider themselves geniuses due to knowing when it is the best time to trade and make fast returns from the stock market, cannot beat the market as they assume. Odean (1998) argues that overconfident investors believe that they are smarter than other investors with regard to selecting the best time to buy shares at the best price. Lim (2012), Bakar and Yi (2016) find that investors' decisions are significantly affected by overconfidence. Moreover, Hon (2012) concluded that small investors in the Hong Kong Stock Market were overconfident. Longjie and Anfeng (2017) find a positive correlation between overconfidence and investment level in the Chinese Stock Market. Scheinkman and Xiong (2003) find that overconfidence causes a speculative bubble. A recent study by Riaz and Iqbal (2015) found that overconfidence has a significant and positive impact on investment decisions regarding the Karachi Stock exchange.

\section{2}

Herd behaviour, where individual investors follow the trend of the market. Therefore, instead of using their own information when making decisions, they simply follow what other investors do. In fact, many investors may not respond instantaneously to new information but rather may base their actions on the trading activities of those 
investors who are believed to be well-informed. Banerjee (1992) argues that herding behaviour occurs when investors look to other investors' behaviour because they believe that others possess more information. He argues that, in a herding environment, a snippet of news may result in a large change in price. This may lead all of the participants in the stock market to make the wrong decision. Chiang and Zheng (2010) and Bikhchandani and Sharma (2001) find that herd behaviour has a negative impact on the stock market, as it may cause volatility, bubbles, and over/undervalued stocks. The impact of herd behaviour can negatively affect the market's supply and demand mechanism. The studies of both Balcilar and Demirer (2015) and Shams and Passand (2015) find that herding behaviour happens in stock markets with high volatility stocks. Moreover, herd behaviour has been found in numerous stock markets around the world, including advanced and Asian stock markets (Chiang and Zheng, 2010). Hon (2012) found that small investors in the Hong Kong Stock Market follow herd behaviour. Choi and Skiba (2015) find herd behaviour in 41 stock markets around the world. However, traders on the KSE can be divided into two groups: investors and speculators. Speculators lack a target price and their expectations for future gain are directly proportional to the absolute price of the stock. This, in turn, could introduce bias into their actions. In fact, in a small country like Kuwait, with its special social characteristics, the trading activity of one investor convey information to another investor that can cause the latter to react fast and causing herd behaviour in the market.

\section{3}

Optimism, where optimistic investors are confident that the market will perform well and that the prices will continue to rise. Moreover, if this optimism is based on solid information about the company and supported by sound economic indicators, it will have a positive impact on the market. However, excessively optimistic investors may inflate the prices by issuing false indicators to other investors. It is common to find that some investors are more likely to act on the basis of their forecasts; if they are overly optimistic, they will cause the prices to shoot up and, if they are overly pessimistic, they will impact the market negatively. Numerous studies have been carried out in this area, including Tariq and Ullah (2013) regarding the Pakistani Stock Market and Tran (2017) regarding the Thai Stock Market.

\section{4}

Risk appetite, where investors dislike risk, behave carefully in order to minimise the uncertainty in the market and make rational decisions. In practice, no market is likely to be comprised solely of rational investors. Not all investors exhibit the characteristics of rationality (Antoniou, Ergul, \& Holmes, 1997); for example, many investors in emerging markets may exhibit risk-loving behaviour. Antoniou et al. (1997), Anderson and Galinsky (2006), and Lansing and LeRoy (2014) investigate the risk-lover investors and conclude that few of investors behave as risk lovers when they face cash needs. Based on the recent literature, this study examines the role of psychological factors on the decisions of individual investors regarding KSE. These psychological factors are, namely: overconfidence, excessive optimism, herd behaviour, and risk appetite. It is hoped that this study will contribute positively to the development of this research area with regard to KSE.

\section{Kuwait Stock Exchange}

As mentioned earlier, the Kuwait Stock Exchange (KSE) established in 1977, since when it has gone through several developments' stages. KSE was closed from 2 August 1990 (the date of the Iraqi invasion) to 28 September 1992. In 2008, the world financial crises affected all of the stock markets worldwide, including KSE. In 2009, Kuwait started to develop its stock exchange by issuing several regulations. The most important was Law No. 7 of 2010 regarding the Establishment of the Capital Market Authority (CMA). Since that date, the Capital Market Authority (CMA) has issued further regulations, aiming to upgrade KSE to the level of the other emerging stock markets across the world; for example, FTSE promoted KSE to emerging in 2018, while MSCI noted that it would include the Kuwait Index as part of its review in 2019. KSE will be upgraded to an emerging market on S\&P and the Dow Jones on 23 September 2019. These developments have had a positive impact on Kuwaiti investors' behaviour regarding the market. Figure 1 shows that the KSE Index decreased from 15615 points on 23 June 2008 and reached 6369 points on 2 January 2018.

The daily return of the market Price Index, represented by the continuously compounded return, is calculated as follows:

$$
R_{t}=\ln \left(\frac{p_{t}}{p_{t-1}}\right)
$$


where $R_{t}$ is the continuously compounded return in period $\mathrm{t}, p_{t}$ is the closing index price at the period $\mathrm{t}$, and $p_{t-1}$ is the closing index price at the period t-1. Figure (2) shows the daily Kuwait Stock Exchange Index returns for the period 2 January 2006 to 26 December 2017.
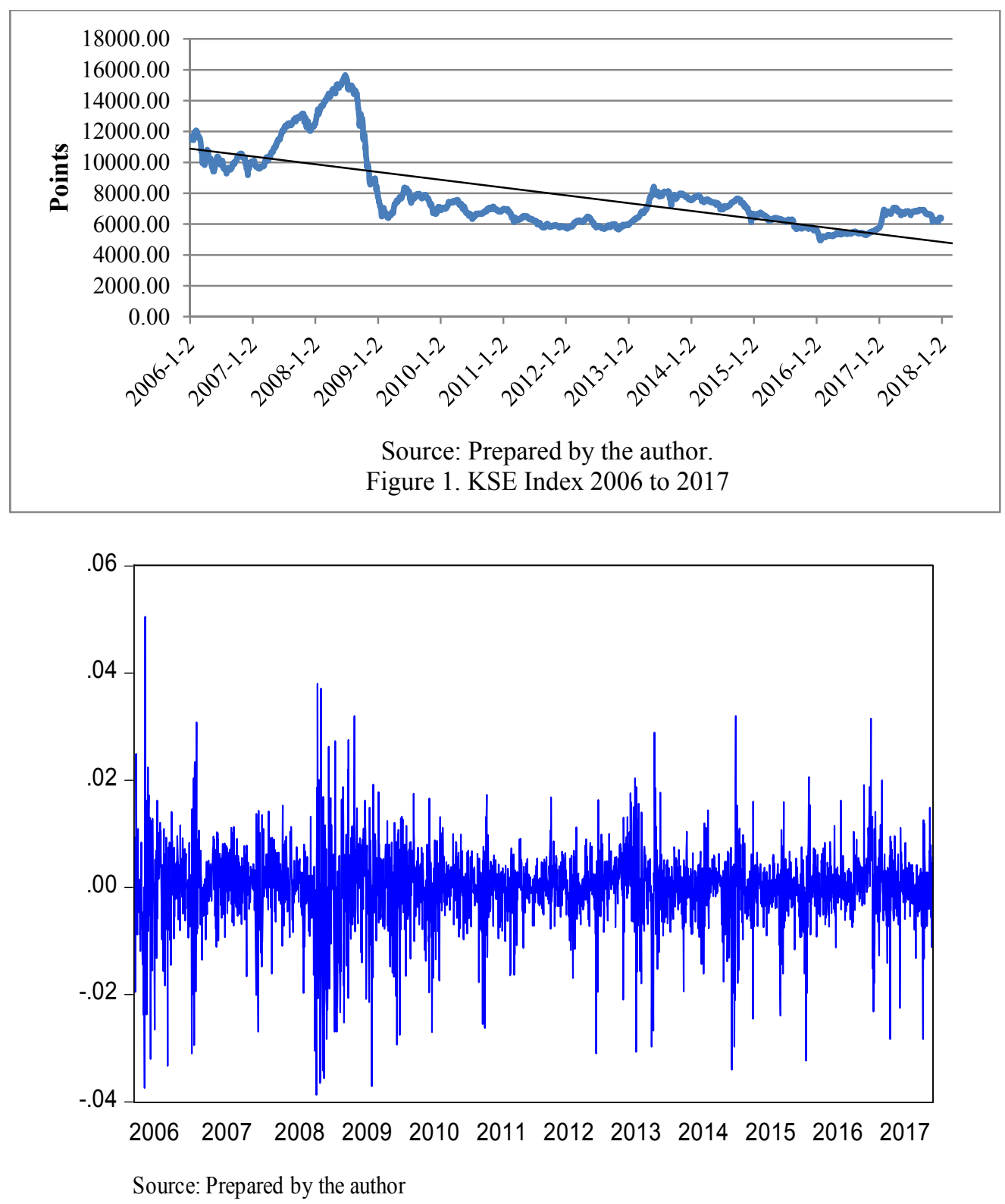

Figure 2: Daily Returns of KSEI 2006 -2017

Table 1. Descriptive Statistics of KSEI returns

\begin{tabular}{cc}
\hline Statistics & Results \\
\hline Mean & -0.00019 \\
Standard Error & 0.000134 \\
Median & 0.000174 \\
Standard Deviation & 0.007394 \\
Kurtosis & 5.11595 \\
Skewness & -0.69605 \\
Range & 0.089214 \\
\hline
\end{tabular}




$\begin{array}{cc}\text { Minimum } & -0.03875 \\ \text { Maximum } & 0.050469 \\ \text { Sum } & -0.58239 \\ \text { Count } & 3032\end{array}$

Source: Prepared by the author.

Table 1 shows the descriptive statistics for the daily return of KSEI. The kurtosis is 5.12, which indicates that the return of KSEI has a distribution with tails thicker than normal. However, the skewness test was used to measure the extent to which the probability distribution has a positive or negative tail with respect to its departure from symmetry. Normal distribution skewness must be zero or near zero, and the result obtained here was -.69605, which is a negative tail and not zero. Moreover, the historical volatility (HV) is computed by taking the standard deviation (SD) of price changes over the month, quarter, and year, and is usually compared with the implied volatility in pricing. It is directly related to the level of risk associated with security. This was done using the following equations:

From equation (1), historical volatility standard deviation (HVSD) by;

$$
\begin{gathered}
\text { HVSD }=\sqrt{\frac{\sum_{t=1}^{n}\left(R_{t}-R_{\text {avg }}\right)^{2}}{n-1}} \\
R_{\text {avg }}=\frac{\sum_{t=1}^{n} R_{t}}{n} \\
\text { Annualized HVSD }=\sqrt[\sqrt{n}]{\frac{\sum_{t=1}^{n}\left(R_{t}-R_{\text {avg }}\right)^{2}}{n-1}}
\end{gathered}
$$

Where $R_{\text {avg }}$ is the average return over the period, $\mathrm{n}$ is the number of periods per year, month and quarter. Figure 3 shows KSE volatility for the period 2006 to 2017. Several factors might cause the market to be highly volatile, such as macroeconomics, politics, world financial indicators, and psychological factors, such as herding, overconfidence, and optimism. Since this study will investigate the effects of psychological factors on individual investors, it may be argued here that these factors may cause KSE to be more volatile. However, this study will not investigate the factors underlying the volatility of KSE.

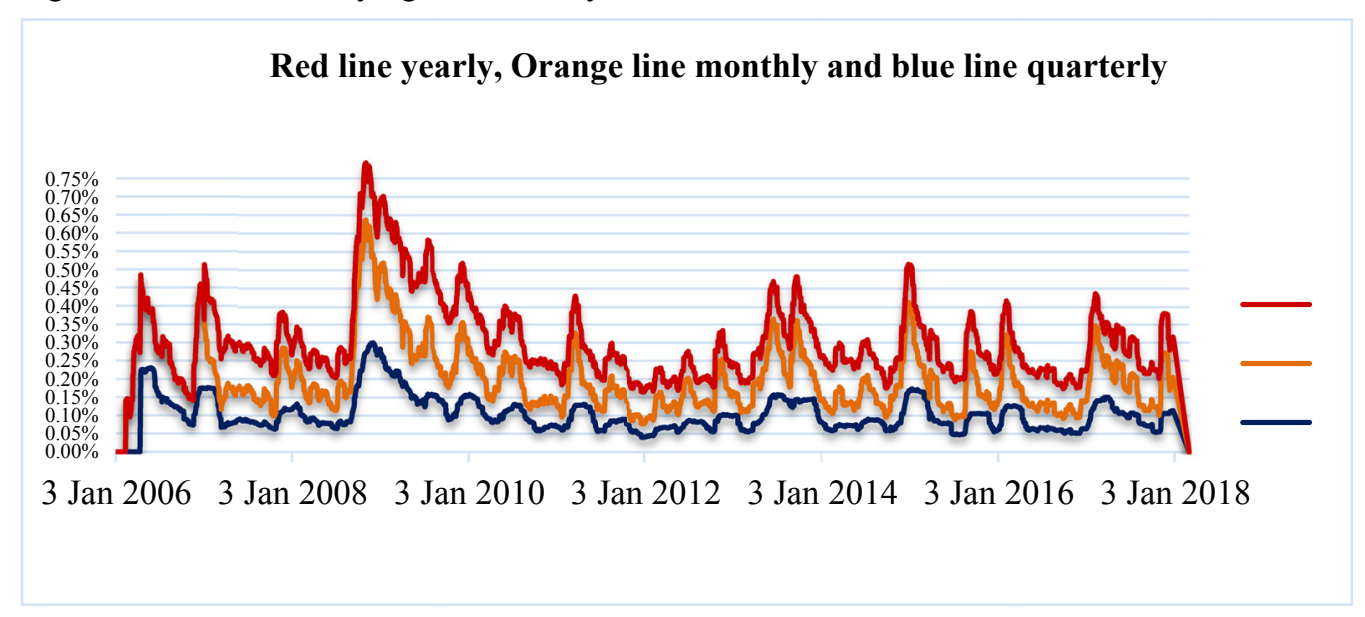

Source: Prepared by the Author.

Figure 3. KSE Index historical volatility

\section{Methodology}

The main objectives of this study are to answer the following questions:

1. Are individual investors in KSE affected by psychological factors when making investment decisions?

2. If so, what are the main factors that influence investors' behaviour?

Moreover, the purpose of this study is to investigate the effects of psychological factors on investors' decisions regarding KSE. These factors are as follows: overconfidence, optimism vs pessimistic, risk appetite and herd behavior. 


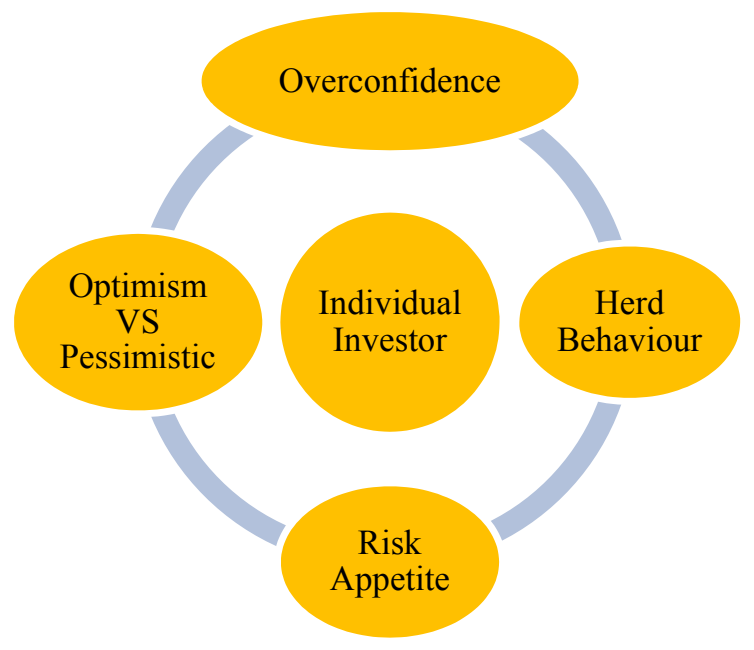

Figure 4. Psychological factors

Figure 4 shows the main factors that affect individual investors in the stock markets. This study employs a qualitative method and uses the simple percentage analysis as suggested McCormick, T. (1945). A survey was constructed and distributed in person and by phone. The population of this study is active investors in KSE. According to KSE, it had 17,821 active investors at the end of 2017. The size of the sample is calculated by using the following formula:

$$
\text { Sample Size }=\frac{\frac{z^{2 \times p(1-p)}}{e^{2}}}{1+\left(\frac{z^{2 \times p(1-p)}}{e^{2} N}\right)}
$$

Where $\mathrm{N}$ is the population size, e the margin of error, $\mathrm{z}$ the confidence level, and $\mathrm{p}$ the percentage value. By applying Equation (5), the sample size is 377 , with a confidence level of $95 \%$. Five hundred surveys were distributed randomly, and 398 completed surveys were returned. The multiple-choice questions were designed to examine the impact of psychological factors. Short, simple and direct questions can be asked when using multiple choice questions. Investors in the stock market are always busy and do not have time to answer a long survey and many questions. Therefore, this study uses a questionnaire with eight questions to investigate the impact of the aforementioned factors on investors' behaviour. The questionnaire asked about the following:

1. Q1. The age of the investor: 1. 22-30, 2. 31-41, and 3. Over 41.

2. Q2. Education: 1. High school, 2. College diploma (two years after high school), and 3. University Degree and above.

3. Q3. Overconfidence and herd behaviour: which is the most important factor that you base your decisions on when buying shares?; 1. Based on my information and personal analysis, and I trust my personal investment decisions, 2. I buy shares when I see many investors buying them, and I follow the market participants, 3. I use fundamental analysis and ask experts about the company before I buy shares, 4. I employ a technical analysis when buying shares. Herd behaviour can be measured based on the response to answer choice 2 .

4. Q4. Optimistic vs pessimistic behaviour: when the market index is losing value daily, I do the following: 1. I sell my shares immediately, 2. I wait until the index increases and sell them again. 3. I buy more shares while the index is decreasing, 4. I do not care if the index loses value because I buy shares for a long-term investment.

5. Q5. Rick appetite: as an investor, I would describe myself as follows: 1. I love risk and risk is a crucial factor for investors' success, 2. As an investor, I know the right time to buy and sell shares, 3. I am a long-term investor and wait every year for evidence, 4. My strategy is to buy and sell the same shares when the market increases and I am a short-term investor.

6. Q6-Q8. The background and views of investors regarding the new regulation of KSE. Q6. Are you familiar with the new regulations of KSE? Q7. Do you think that KSE has been developed by these new regulations? Q8. Do you prefer to manage your portfolio yourself or do you use investment companies? The answer for these questions is either 1.yes or 2 . No. 


\subsection{Cronbach's Alpha}

The Cronbach's alpha is a measure used to assess the reliability or internal consistency of a set of scale or test items. It was developed by Cronbach (1951) to evaluate items scored in multiple answer categories and is an important measure of the questioner's reliability. The Cronbach's Alpha formula is as follows:

$$
\alpha=\frac{(N \cdot \bar{c})}{\bar{v}+(N-1) \cdot \bar{c}}
$$

where $\mathrm{N}$ is the number of items, $\overline{\mathrm{c}}$ the average covariance between the item-pairs, and $\overline{\mathrm{v}}$ the average variance.

Table 2. Cronbach's Alpha

\begin{tabular}{cc}
\hline Cronbach's alpha & Internal consistency \\
\hline $0.9 \leq \alpha$ & Excellent \\
$0.8 \leq \alpha<0.9$ & Good \\
$0.7 \leq \alpha<0.8$ & Acceptable \\
$0.6 \leq \alpha<0.7$ & Questionable \\
$0.5 \leq \alpha<0.6$ & Poor \\
$\alpha<0.5$ & Unacceptable
\end{tabular}

Source: Cronbach LJ (1951).

By applying the Cronbach's Alpha formula, the alpha coefficient for the eight questions was found to be 0.998 , suggesting that the questions have a high degree of internal consistency.

\section{Results and Discussion}

STATA, statistical data analysis software version 15.1, and Excel were used in this study. Table 3 shows that $45.5 \%$ of the total participants in the survey were aged $31-40$ years old, and $37.2 \%$ were over 40 years old. These results indicate that $82.7 \%$ of the respondents in the sample are over 31 years old, which is an age of mature and logical thinking. University education and higher degree represent $77.9 \%$ of the total participants. This result may also have a positive impact on the results since most of our respondents are well-educated and they have higher degrees, which leads us to expect their decisions to be more mature. Few of our sample (individual investors in KSE) have an overconfident attitude in their ability, as this was expressed by only $7.5 \%$ of the respondents. It is worth noting that all of these participants are over 40 years old. (see Tables 1 to 14 in the Appendix). This finding was unexpected and conflicted with other studies on emerging markets, such as Lim (2012), Bashir et al. (2013), Tariq and Ullah (2013), and Bakar and Yi (2016). The same table shows that $43.2 \%$ of the participants in this survey make their investment decisions by following the market trends (other investors). This percentage can be broken down as follows: 38 of these respondents were aged 22 to 30,67 aged between 31 to 40 , and 68 over 40 . Since participants from all of the age groups follow the market trend, this may be an indicator that herd behaviour is widespread among individual investors in KSE. This result is similar to research by Al-Tuhaih (1983), Abul (2003), Shabgou and Mousavi (2016), and Tran (2017). This factor may cause volatility in KSE. The results indicate that $18.6 \%$ of the respondents use a fundamental analysis, which takes time and requires either educated individual investors or investment institutions that seek long-term investments.

However, individual Kuwaiti investors are familiar with technical analysis, and several groups on social media such as Facebook, Twitter, and blogs have created windows for chatting and giving technical analysis advice for all of the listed shares on KSE. Table 3 shows that $30.7 \%$ of the sample used a technical analysis when making decisions about buying and selling shares.

The optimistic behaviour of individual Kuwaiti investors can be investigated through the responses to question 4, reported in table 3 , which indicates that $34.2 \%$ of them wait until the stock market picks up again and then sell their shares. Moreover, $24.4 \%$ of them can be described as optimistic investors since they are willing to buy more shares when the market drops sharply. However, $30.9 \%$ of them sell their shares immediately when the market index loses value daily. This result shows that $30.9 \%$ of the respondents are pessimistic when the index undergoes a continuing sharp decline. The same table shows that $10.6 \%$ of the participants do not care if the index loses value every day because they buy shares as a long-term investment. As a result, by combining the responses to questions 1 and 3, we can conclude that $58.6 \%$ of the respondents are optimistic. This finding is consistent with other research by Tariq and Ullah (2013) regarding the Pakistani Stock Market, and Tran (2017) regarding the Thailand Stock Market. 
Table 3. Questionnaire Responses

\begin{tabular}{ccccc}
\hline Question & $1 *$ & $2 *$ & $3 *$ & $4 *$ \\
\hline Q1 & 17.3 & 45.5 & 37.2 & $* *$ \\
Q2 & 4.8 & 17.3 & 77.9 & $* *$ \\
Q3 & 7.54 & 43.1 & 18.6 & 30.7 \\
Q4 & 30.9 & 34.2 & 24.4 & 10.6 \\
Q5 & 23.1 & 14.1 & 11.4 & 51.5 \\
Q6 & 63.8 & 36.2 & $* *$ & $* *$ \\
Q7 & 51.3 & 48.7 & $* *$ & $* *$ \\
Q8 & 61.3 & 38.6 & $* *$ & $* *$
\end{tabular}

Source: Author prepared.

* As a percentage of the total.

** Question 3, 4 and 5 have 4 multiple choices.

Half of the participants in this survey (51.5\%) describe themselves as short-term investors, as their strategy in the market is to buy shares and then sell them when the market increases. However, $23.1 \%$ of the participants believe that risk is a crucial factor for investors' success, and $14.1 \%$ believe that, as investors, they know when is the best time to buy and sell shares. Only $11.4 \%$ of them stated that they are long-term investors who wait for the dividend each year. This result is almost the same proportion as for the previous question, Q.4., which is $10.6 \%$.

Questions six to eight require yes/no answers. The results show that $63 \%$ of the respondents know about the new regulations of KSE, which indicates that individual investors in Kuwait are familiar with the new regulations of KSE. Moreover, $51.3 \%$ of them agreed that these new regulations had developed KSE, and $61.3 \%$ of them are preferred to manage their portfolio themselves.

\section{Conclusion}

This study briefly reviewed the history of KSE and discussed some of the features of the market, such as its volatility and the main crisis period from 2006 to 2017. This study examined the impact of psychological factors on individual investors' decisions regarding KSE. A survey containing eight questions was distributed to 500 randomly selected individual investors, and 389 completed responses were received. The results of the surveys confirm that psychological factors, like herd behaviour, optimism, pessimism and risk, do affect investors' decisions regarding KSE. However, we did not find a solid result to support the effects of overconfidence on individual Kuwaiti investors. Our results are consistent with other studies, such as Antoniou et al. (1997), Anderson and Galinsky, (2006), Hon (2012), Lansing and LeRoy (2014), Chiang and Zheng (2010), Choi and Skiba (2015), Balcilar and Demirer (2015), and Shams and Passand (2015).

However, the limitations of this research is that the sample is based only on individual investors and does not include institutional firms. It would be helpful to conduct further research that employed a larger sample and included all types of investors. Moreover, the analysis in this research done by using a percentage analysis of the questioner's answers, however, this analysis can be more fruitful if it included advanced tools such as probability and non-probability methods, rigorous analysis, and empirical tools such as correlation and regression analysis between the factors.

\section{References}

Abul, S. (2003). An Examination of the Efficiency of the Kuwait Stock. The Industrial Bank of Kuwait Papers, Series No.73, June 2003, Kuwait. Retrieved from https://www.ibkuwt.com/ibk/web/en/

Akhtar, M., \& Batool, I. (2012). Psychological Factors, Information Asymmetry and Investment Decision-Making. Actual Problems of Economics, 2(4), 200-205. Retrieved from https://www.researchgate.net/publication/236950135

Al-Tuhaih, S. (1983). The Securities Market in Kuwait. A report published by Amiri Diwan, Office of Research of His Highness the Amir, Kuwait.

Anderson, C., \& Galinsky, A. (2006). Power, optimism, and risk-taking. European Journal of Social Psychology, 36, 511-536. https://doi.org/10.1002/ejsp.324 
Antoniou, A., Ergul, N., \& Holmes, P. (1997). Market efficiency, thin trading and non-linear behaviour: evidence from an emerging market. European Financial Management, 3(2), 175-190. https://doi.org/10.1111/1468-036X.00038

Bakar, S., \& Yi, A. (2016). The Impact of Psychological Factors on Investors' Decision Making in Malaysian Stock Market: A Case of Klang Valley and Pahang. Procedia Economics and Finance, 35, 319-328. https://doi.org/10.1016/S2212-5671(16)00040-X

Balcilar, M., \& Demirer, Z. (2015). Impact of Global Shocks and Volatility on Herd Behaviour in an Emerging Market: Evidence from Borsa Istanbul. Emerging Markets Finance and Trade, 51. https://doi.org/10.2139/ssrn.2350457

Banerjee, A. (1992). A Simple Model of Herd Behaviour. Quarterly Journal of Economics, 107, 797-817. https://doi.org/10.2307/2118364

Barber, B., \& Odean, T. (2001). Boys Will Be Boys: Gender, Overconfidence, and Common Stock Investment. The Quarterly Journal of Economics, 116(1), 261-292. https://doi.org/10.1162/003355301556400

Bikhchandani, S., \& Sharma, S. (2001). Herd Behaviour in Financial Markets. IMF Staff Papers, 47(3). Retrieved from https://www.imf.org/External/Pubs/FT/staffp/2001/01/bikhchan.htm

Birau, F. R. (2011a). Behavioural Finance Paradigm and Its Implications on Investment Decisions. International Scientific Conference; ECO-TREND 2011 - Exit From The Crisis And Revival Of Sustainable Growth", 8th edition, November 25-26, 2011, T.G. - Jiu, Romania. Retrieved from https://www.researchgate.net/publication/258698903

Birau, F. R. (2011b). The meanings of efficient market paradigm in the context of emerging capital markets. An analysis of weak-form efficiency on the Bucharest Stock Exchange. The International Conference; Competitiveness and Stability in The Knowledge-Based Economy, The Faculty of Economics and Business Administration, University of Craiova, Romania, 4-5 November 2011

Birau, F. R. (2012). The Impact of Behavioural Finance on Stock Markets. Annals of the Constantin Brâncuşi” University of Târgu Jiu, Economy Series, Issue 3/2012. Retrieved from https://www.researchgate.net/publication/258698903

Camerer, C. F., \& Loewenstein, G. (2004). Behavioural Economics: Past, Present, and Future. in Advances in Behavioural Economics C. F. Camerer, G. Loewenstein and M. Rabin, Eds., New York: Russell Sage Foundation. Retrieved from https://press.princeton.edu/titles/7607.html

Chiang, T. C., \& Zheng, D. (2010). An empirical analysis of herd bahaviourin global stock markets. Journal of Banking and Finance, 34, 1911-1921. https://doi.org/10.1016/j.jbankfin.2009.12.014

Choi, N., \& Skiba, H. (2015). Institutional herding in international markets. Journal of Banking and Finance, 55, 246-259. https://doi.org/10.1016/j.jbankfin.2015.02.002

Cronbach, L. J. (1951). Coefficient alpha and the internal structure of tests. Psychometrika, 16, 297-334 (28,307 citations in Google Scholar as of 4/1/2016). https://doi.org/10.1007/BF02310555

Daniel, K., \& Hirshleifer, D. (2015). Overconfident Investors, Predictable Returns, and Excessive Trading. Journal of Economic Perspectives, 29(4), 61-88. https://doi.org/10.1257/jep.29.4.61

Daniel, K., Hirshleifer, D., \& Teoh, S. H. (2002). Investor Psychology in Capital Markets: Evidence and Policy $\begin{array}{llll}\text { Implications. Journal of Monetary Economics, } & 49(1),\end{array}$ https://doi.org/10.1016/S0304-3932(01)00091-5

Dhaoui, A. (2015). What Does Matter in Economy Today: When Human Psychology Drives Financial Markets. Arab Economics and Business Journal, 10, 39-47. https://doi.org/10.1016/j.aebj.2014.12.002

Edwards, W. (1954). The theory of decision making. Psychological Bulletin, 41, 380-417. https://doi.org/10.1037/h0053870

Edwards, W. (1961). Behavioural decision theory. Annual Review of Psychology, 12, 473. https://doi.org/10.1146/annurev.ps.12.020161.002353

Fama, E. F. (1965). The behaviour of stock markets prices. Journal of Business, 38(1), 34-105. https://doi.org/10.1086/294743

Fama, E. F. (1970). Efficient Capital Markets: a review of theory and empirical work. Journal of Finance, 25, 383-417. https://doi.org/10.2307/2325486 
Fama, E. F. (1991). Efficient Capital Markets II. Journal of Finance, 46, 1575-1617. https://doi.org/10.1111/j.1540-6261.1991.tb04636.x

Farooq, A., Afzal, M. A., Sohil, N., \& Sajid, M. (2015). Factors affecting investment decision making: evidence from equity fund managers and individual investors in Pakistan. Journal of Basic and Applied Scientific Research, 5(8), 62-69. https://doi.org/10.1504/AAJFA.2014.059500

Gupta, Y., \& Ahmed, S. (2016). The impact of psychological factors on investment decision making of investors: an empirical analysis. International Journal of the Economic and Business Review, 4(11), 40-52. https://doi.org/10.1016/S2212-5671(16)00040-X

Hirshleifer and Luo. (2001). On the survival of overconfident traders in a competitive securities market. Journal of Financial Markets, 4, 73-84. https://doi.org/10.1016/S1386-4181(00)00014-8

Hon, T. (2012). The Behaviour of Small Investors in the Hong Kong Derivatives Markets: A factor analysis. Journal of Risk and Financial Management, 5, 59-77. https://doi.org/10.3390/jrfm5010059

Kahneman, D., \& Tversky, A. (1997). Prospective theory: An analysis of decision under risk. Econometrica, 47, 263-291. https://doi.org/10.5296/ajfa.v6i1.4893

Kengatharan, L., \& Kengatharan, N. (2014). The Influence of Behavioural Factors in Making Investment Decisions and Performance: Study on Investors of Colombo Stock Exchange, Sri Lanka. Asian Journal of Finance \& Accounting, 6(1), 2-23. doi:10.5296/ajfa.v6i1.4893

Lansing, K. J., \& LeRoy, S. F. (2014). Risk Aversion, Investor Information, and Stock Market Volatility. Federal Reserve Bank of San Francisco, Working Paper 2010-24, 2014. https://doi.org/10.1016/j.euroecorev.2014.03.009

Lim, L. C. (2012). The Relationship between Psychological Biases and the Decision Making of Investor in Malaysian Share Market. International Conference on Management, Economics \& Finance (ICMEF 2012) Proceeding. Retrieved from http://iosrjournals.org/iosr-jbm/papers/Vol10-issue3/G01036068.pdf

Longjie, X., \& Anfen, Z. (2017). The Impact of Managers Overconfidence on Corporate Investment. International Journal of Social Science and Humanity, 7(2). https://doi.org/10.18178/IJSSH

Mitroi, A., \& Oproiu, A. (2014). Behaviour finance: new research trends, Socioeconomics and investor emotions. Theoretical and Applied Economics, 11(4) (593), 153-166.

Mitroi, Adrian. (2016). Post Behavioural Finance Adolescence. Annals of the Constantin Brâncuşi. University of Târgu Jiu, Economy Series, Special Issue, 1, 206-218.

Odean, T. (1998). Are investors reluctant to realize their losses? The Journal of Finance, 53(5), 1775-1798. https://doi.org/10.1111/0022-1082.00072

Odean, T. (1998). Volume, volatility, price, and profit when all traders are above average. Journal of Finance, 53, 1887-1934. https://doi.org/10.1111/0022-1082.00078

Phan, K. C., \& Zhou, J. (2014). Factors Influencing Individual Investor Behaviour: An Empirical Study of the Vietnamese Stock Market. American Journal of Business and Management, 3(2), 77-94. https://doi.org/10.11634/216796061403527

Riaz, I., \& Iqbal, H. (2015). Impact of Overconfidence, Illusion of control, Self-Control and Optimism Bias on Investors Decision Making; Evidence from Developing Markets. Research Journal of Finance and Accounting, 6(11), 110-115.

Riaz, L., \& Hunjra, A. I. (2015). Relationship between Psychological factors and Investment Decision Making: The Mediating Role of Risk Perception. Pakistan Journal of Commerce and Social Sciences, 9, 968-981. Retrieved from https://www.researchgate.net/publication/316430822

Scheinkman, J. A., \& Xiong, W. (2003). Overconfidence and Speculative Bubbles. Journal of Political Economy, 111(6), 1183-1219. https://doi.org/10.1086/378531

Shabgou, M., \& Mousavis, A. (2016). Behavioural Finance: Behavioural Factors Influencing Investors Decisions Making. Advanced Social Humanities and Management 3(1), 1-6. Retrieved from https://pdfs.semanticscholar.org/e500/b362c129c1e024c7b2a3cf49f6be

Shams, S., \& Passand, A. (2015). The Relationship between Investors Herding and Volatility: Evidence from Tehran Stock Exchange. Iranian Journal for business and economics, 2(3), 1-6. Retrieved from http://www.scijour.com/page/download-C703DgFRCWY.artdl 
Shiller, R. J. (2015). Irrational Exuberance: Revised and Expanded (3rd ed.). Princeton: Princeton University Press. https://doi.org/10.1515/9781400865536

Tariq, B., \& Ullah, N. (2013). Investor overconfidence and stock returns: Evidence from Pakistan. Journal of Business and Management, 8, 77-84.

Thaler, R. H. (2015). Misbehaving: The Making of Behavioural Economics. New York: W.W Norton \& Company Inc.

Ton, H. T. H., \& Dao, T. K. (2014). The effects of Psychology on Individual Investors' Behaviour: Evidence from the Vietnam Stock Market. Journal of Management and Sustainability, 4(3), 125-133. https://doi.org/10.5539/jms.v4n3p125

Tran, Q. (2017). The behaviour Patterns of investors in the Thailand Stock Market. Asian Journal of Finance \& Accounting, 9(1), 155-165. https://doi.org/10.5296/ajfa.v9i1.10605

Tversky, A., \& Kahneman, D. (1974). Judgment under Uncertainty: Heuristics and Biases. Science, New series, 185(4157), 1124-1131. https://doi.org/10.1126/science.185.4157.1124

Wang, A. (2001). Overconfidence, investor sentiment and evolution. Journal of Financial Intermediation, 10(2), 138-170. https://doi.org/10.1006/jfin.2001.0311

\section{Appendix}

\section{Stata Results for the Survey}

Table 1. Results of question 1; Participants by age

\begin{tabular}{cccc}
\hline Age (years) & Freq. & $\%$ & Cum \\
\hline $22-30$ & 69 & 17.34 & 17.34 \\
$31-40$ & 181 & 45.48 & 62.81 \\
Above 40 & 148 & 37.19 & 100 \\
Total & 398 & 100 & \\
\hline
\end{tabular}

Table 2. Results of question 2; Participants by Education

\begin{tabular}{cccc}
\hline Education & Freq. & \% & Cum \\
\hline High School & 19 & 4.77 & 4.7 \\
Diploma (2 years after high school) & 69 & 17.34 & 22.1 \\
University degree and higher & 310 & 77.89 & 100 \\
\hline Total & 398 & 100 & \\
\hline
\end{tabular}

Table 3. Results of question 3: Participants by age

\begin{tabular}{cccccc}
\hline Age & $1 *$ & $2 *$ & $3 *$ & $4 *$ & Total \\
\hline $22-30$ & 0 & 38 & 0 & 31 & 69 \\
$31-40$ & 0 & 67 & 48 & 66 & 181 \\
Above 40 & 30 & 68 & 25 & 25 & 148 \\
Total & 30 & 173 & 73 & 122 & 398 \\
\hline
\end{tabular}

*Multiple choices

Table 4. Results of question 3: Participants by education

\begin{tabular}{cccccc}
\hline Education & $1^{*}$ & $2^{*}$ & $3^{*}$ & $4^{*}$ & Total \\
\hline High School & 0 & 0 & 19 & 0 & 19 \\
Diploma (2 years after high school) & 0 & 45 & 0 & 24 & 69 \\
University degree and higher & 30 & 128 & 54 & 98 & 310 \\
\hline Total & 30 & 173 & 73 & 122 & 398 \\
\hline
\end{tabular}

*Multiple choices 
Table 5. Results of question 4: Participants by age

\begin{tabular}{cccccc}
\hline Age & $1 *$ & $2 *$ & $3 *$ & $4 *$ & Total \\
\hline $22-30$ & 12 & 12 & 45 & 0 & 69 \\
$31-40$ & 78 & 52 & 25 & 26 & 181 \\
Above 40 & 33 & 72 & 27 & 16 & 148 \\
Total & 123 & 136 & 97 & 42 & 398 \\
\hline
\end{tabular}

* Multiple choices

Table 6. Results of question 4: Participants by education

\begin{tabular}{cccccc}
\hline Education & $1^{*}$ & $2^{*}$ & $3^{*}$ & $4^{*}$ & Total \\
\hline High School & 9 & 10 & 0 & 0 & 19 \\
Diploma (2 years after high school) & 11 & 42 & 16 & 0 & 69 \\
University degree and higher & 103 & 84 & 81 & 42 & 310 \\
\hline Total & 123 & 136 & 97 & 42 & 398
\end{tabular}

* Multiple choices

Table 7. Results of question 5: Participants by age

\begin{tabular}{cccccc}
\hline Age & $1^{*}$ & $2^{*}$ & $3^{*}$ & $4^{*}$ & Total \\
\hline $22-30$ & 29 & 26 & 0 & 14 & 69 \\
$31-40$ & 41 & 30 & 26 & 84 & 181 \\
Above 40 & 22 & 0 & 20 & 106 & 148 \\
Total & 92 & 56 & 46 & 204 & 398 \\
\hline
\end{tabular}

* Multiple choices

Table 8. Results of question 5: Participants by education

\begin{tabular}{cccccc}
\hline Education & $1^{*}$ & $2^{*}$ & $3^{*}$ & $4^{*}$ & Total \\
\hline High School & 0 & 0 & 0 & 19 & 19 \\
Diploma (2 years after high school) & 12 & 0 & 11 & 46 & 69 \\
University degree and higher & 80 & 56 & 35 & 139 & 310 \\
\hline Total & 92 & 56 & 46 & 204 & 398 \\
\hline
\end{tabular}

* Multiple choices

Table 9. Results of question 6: Participants by age

\begin{tabular}{cccc}
\hline Age & $1^{*}$ & $2 *$ & Total \\
\hline $22-30$ & 45 & 24 & 69 \\
$31-40$ & 131 & 50 & 181 \\
Above 40 & 78 & 70 & 148 \\
\hline Total & 254 & 144 & 398 \\
\hline
\end{tabular}

* Multiple choices

Table 10. Results of question 6: Participants by education

\begin{tabular}{cccc}
\hline Education & $1 *$ & $2 *$ & Total \\
\hline High School & 19 & 0 & 19 \\
Diploma (2 years after high school) & 29 & 40 & 69 \\
University degree and higher & 206 & 104 & 310 \\
\hline Total & 254 & 144 & 398 \\
\hline
\end{tabular}

* Multiple choices 
Table 11. Results of question 7: Participants by age

\begin{tabular}{cccc}
\hline Age & $1^{*}$ & $2^{*}$ & Total \\
\hline $22-30$ & 43 & 26 & 69 \\
$31-40$ & 117 & 64 & 181 \\
Above 40 & 44 & 104 & 148 \\
\hline Total & 204 & 194 & 398 \\
\hline
\end{tabular}

* Multiple choices

Table 12. Results of question 7: Participants by education

\begin{tabular}{cccc}
\hline Education & $1^{*}$ & $2^{*}$ & Total \\
\hline High School & 9 & 10 & 19 \\
Diploma (2 years after high school) & 29 & 40 & 69 \\
University degree and higher & 166 & 144 & 310 \\
\hline Total & 204 & 194 & 398 \\
\hline
\end{tabular}

* Multiple choices

Table 13. Results of question 8: Participants by age

\begin{tabular}{cccc}
\hline Age & $1^{*}$ & $2^{*}$ & Total \\
\hline $22-30$ & 31 & 38 & 69 \\
$31-40$ & 153 & 28 & 181 \\
Above 40 & 60 & 88 & 148 \\
\hline Total & 244 & 154 & 398 \\
\hline
\end{tabular}

* Multiple choices

Table 14. Results of question 8: Participants by education

\begin{tabular}{cccc}
\hline Education & $1^{*}$ & $2^{*}$ & Total \\
\hline High School & 9 & 10 & 19 \\
Diploma (2 years after high school) & 30 & 39 & 69 \\
University degree and higher & 205 & 105 & 310 \\
\hline Total & 244 & 154 & 398 \\
\hline
\end{tabular}

* Multiple choices

\section{Copyrights}

Copyright for this article is retained by the author(s), with first publication rights granted to the journal.

This is an open-access article distributed under the terms and conditions of the Creative Commons Attribution license (http://creativecommons.org/licenses/by/4.0/). 